\title{
Antropologia e a crise dos modelos explicativos
}

\author{
ROBERTO CARDOSO DE OLIVEIRA
}

$\mathrm{O}$

TEMA QUE ME FOI DADO desenvolver nesta conferência, embora bastante oportuno dada à atualidade dos problemas que gera, é em si mesmo equívoco devido ao caráter polissêmico do termo crise. Por essa razão, começaria minhas considerações sobre o conceito de crise, pelo menos na forma pela qual ele tem sido utilizado na antropologia. Posteriormente, procurarei distinguir modelo explicativo - que estou entendendo aqui como equivalente a paradigma - de teoria. Finalmente concluirei por uma tentativa de avaliação da vocação explicativa de alguns paradigmas constitutivos de nossa disciplina frente ao caráter compreensivo inerente ao próprio métier do antropólogo. Minha expectativa é de que possamos, juntos, aprofundar o exame do tema proposto, pois as idéias que apresentarei a seguir não devem ser tomadas senão como pontos de referência capazes de orientar o debate, porém jamais limitá-lo.

A noção de crise passou a habitar o horizonte das ciências sociais - e não apenas da antropologia - nessas últimas décadas a partir do celebrado livro de Thomas Kuhn, A estrutura das revoluções científicas, cuja primeira edição remonta ao início dos anos 60 . Tratava-se então de uma crise de paradigmas, na qual, no modo de ver de Kuhn, a história das ciências paradigmáticas (isto é, das hard sciences) constituía uma sucessão de crises, que somente poderia ser superada pela substituição do paradigma vigente na ciência normal por um novo, resultado de uma espécie de revolução científica. Muito se escreveu em decorrência da posição desse historiador da ciência, originalmente um físico, que a rigor procurava renovar a história da ciência, trazendo ao debate argumentos, inclusive, de forte apelo sociológico - como o do paradigma se assentar em comunidades de profissionais (idéia, aliás, já antecipada por seu compatriota Charles Pierce há pelo menos um século). Não vejo necessidade de evocar aqui todos os elementos que constituem o conceito kuhniano de crise e de paradigma - uma vez que são bastante conhecidos de todos nós -, senão apenas associá-los para qualificar um tipo de crise, que poderíamos chamar de crise epistêmica (1).

A antropologia, enquanto disciplina autônoma, já com alguma anterioridade preocupava-se com a idéia de uma eventual crise que, segundo alguns membros da comunidade de antropólogos, se avizinhava diante do previsível desaparecimento 
de seu objeto de estudo. Seria legítima essa preocupação, ou sequer cabia levá-la a sério? Claude Lévi-Strauss soube levá-la a sério, mas para exorcizá-la. Todos se lembram de seu curto mas interessante artigo, no qual procura mostrar que em hipótese alguma o crescente processo de depopulação das etnias indígenas do planeta, ou mesmo a incorporação dos povos ditos primitivos em grandes civilizações (sobretudo à civilização européia), podem por em risco o futuro da disciplina, uma vez que ela não se define por seu objeto concreto (no caso, as sociedades aborígenes), mas pelo olhar que ela deita sobre a questão da diferença. Questão essa sempre presente onde quer que identidades étnicas se defrontem. Lévi-Strauss (1962:26) conclui seu artigo dizendo que "enquanto as maneiras de ser ou de agir de certos homens forem problemas para outros homens, haverá lugar para uma reflexão sobre essas diferenças, que, de forma sempre renovada, continuará a ser o domínio da antropologia”.

Ou, como diria um filósofo como Merleau-Ponty (1960:150), como fazendo eco ao pensamento de Lévi-Strauss: "A etnologia não é uma especialidade definida por um objeto particular, as sociedades 'primitivas'; é uma maneira de pensar, aquela que se impõe quando o objeto é [o] 'outro', e exige que nós nos transformemos" (o artigo entre colchetes é meu e exprime minha interpretação do texto de Merleau-Ponty).

O argumento elaborado por Lévi-Strauss serve para nos convencer - assim imagino - de que pelo menos o propalado desaparecimento daqueles que têm sido o foco privilegiado da pesquisa antropológica, os povos aborígenes, não pode ser responsável por um eventual desaparecimento da disciplina por falta de objeto... Mas a maior importância do argumento está na transposição do problema do plano dos objetos concretos ao plano das modalidades de conhecimento de qualquer objeto empiricamente observável. Passa-se, assim, ao plano epistemológico - no qual, aliás, se travam atualmente as polêmicas mais interessantes e, certamente, mais proveitosas para o próprio desenvolvimento de nossa disciplina. Gostaria, aqui, de circunscrever a problemática da crise da antropologia, ou de como ela é percebida nas comunidades de profissionais da disciplina, não mais nos centros metropolitanos (onde a antropologia teve a sua origem e se disseminou para a periferia), mas para países onde ela foi obrigada a se adaptar a novas condições de existência, tais como a precariedade institucional (falta de bibliotecas, ausência de tradição universitária, limitação orçamentária etc.), em que pese tais países terem servido (este é o termo) de campo de pesquisa para antropólogos provenientes daqueles centros. Essa adaptação, a que tenho chamado de estilo (num projeto ora em curso sobre a estilística da antropologia, que coordeno na UNICAMP), oferece à reflexão algo que considero muito importante para o progresso da disciplina entre nós e em países congêneres. Trata-se da investigação comparada entre antropologias periféricas, de maneira a propiciar o alargamento do horizonte da disciplina nas áreas não-metropolitanas, graças à apreensão de seus diferentes estilos, a par de proporcionar a oportunidade de um 
saudável intercâmbio entre suas respectivas comunidades de profissionais. Limitar-me-ei aqui - por falta de tempo - a mencionar pelo menos um país irmão, o México, onde a questão da crise não deixou de ter sua repercussão.

O colega Esteban Krotz, antropólogo da Universidade Autônoma de Yucatan, organizou um simpósio na Cidade do México, em 1990, devotado à reflexão sobre "o conceito de 'crise' na historiografia das ciências antropológicas", com quase uma dezena de participantes, cinco dos quais apresentando textos, finalmente publicados num opúsculo de pouco menos de 50 páginas (Krotz, 1982). Todavia, a pequena extensão da coletânea não desmerece a qualidade dos trabalhos postos à disposição do leitor. Eles indicam um conjunto de tópicos que mereceram a atenção dos antropólogos mexicanos e que, em sua maioria, não nos são estranhos. Vamos nos valer aqui de pelo menos uma das contribuições do seminário, precisamente a de seu organizador, uma vez que ele nos oferece um quadro interessante das diferentes percepções da crise no espaço ocupado pela disciplina no México. Com seu texto Crise da antropologia e dos antropólogos, Krotz procura estabelecer, portanto, uma distinção entre os diferentes sentidos que essa crise pode ter em seu país. Mostra que vários tipos de crise podem ser identificadas no México. Dentre os atores intelectuais que falam da crise mexicana, distingue inicialmente três deles que, em sua opinião, não estariam suficientemente familizarizados com a disciplina para sobre ela se manifestarem: são literatos, como Octavio Paz; colegas de outras disciplinas, portanto sem formação em antropologia; e funcionários de alguma maneira ligados à área de aplicação da disciplina e que, no México - sabemos nós - desempenham papel significativo no financiamento do trabalho antropológico certamente em escala muito mais avançada do que ocorre nos demais países latino-americanos (o Estado ocupa um espaço extraordinariamente amplo na sociedade mexicana e pouca coisa se faz sem o seu apoio). Há, ainda, aqueles que possuem maior familiaridade com a antropologia, mas cuja posição pessoal crítica contamina sua avaliação da disciplina: em regra são pessoas envolvidas em seus trabalhos de tese, cuja formação nem sempre adequada gera nelas frustração e ansiedade bastante perturbadoras de seu juízo crítico. Há, finalmente, os profissionais da disciplina, dentre os quais identifica três tipos de atores, cujas avaliações que fazem da antropologia devem - a meu ver - ser levadas a sério. Krotz (1982:11) assim os descreve: “a) quando se esgotam, após intenso esforço, debates sem perspectiva de solução, situação que leva ao esgotamento os próprios antropólogos (exemplo: a discussão sobre o campesinato durante os anos setenta); b) quando se sentem desarmados frente a problemas sociais e culturais relativamente novos e/ou politicamente relevantes (exemplo: os novos movimentos sociais); c) quando verificam na literatura especializada estrangeira e/ou em instituições nacionais fenômenos que interpretados posteriormente como rupturas geracionais ou como meros modismos, parecem tornar tão profundamente obsoletos sucessos científicos recentes que põem em dúvida o potencial da disciplina por inteira”. 
O ponto de vista esboçado por Krotz, à medida em que leva em conta os distintos atores sociais que habitam o campo da antropologia, seja em seu centro, seja em suas proximidades, permite distinguir igualmente certa variedade de representações dessa mesma crise, ampliando, assim, o próprio horizonte da análise de um fenômeno bem mais complexo do que poderia parecer inicialmente. Apesar da realidade mexicana ser substancialmente diferente da brasileira, ainda que as antropologias que vigoram tanto num quanto noutro país tenham indiscutíveis similaridades (que infelizmente aqui não teremos tempo de examinar), o certo é que esse quadro elaborado por Krotz lança uma boa luz sobre considerações que sempre podemos fazer à propósito da propalada crise que, para alguns, sonda a disciplina entre nós. Entretanto, reconhecendo a importância da distinção feita por Krotz relativamente à comunidade mexicana de antropólogos, em sua percepção da crise da disciplina, cabe reconhecer igualmente que não fica claro se a crise está situada em eventual esgotamento do paradigma, seja ele qual for, ou se se trata de inadequação ou superação de teorias relativas às realidades ou problemas investigados. Essa é uma questão que eu gostaria de examinar agora, especificamente com relação ao exercício da antropologia em nosso país.

Tenho para mim que muito daquilo que se diz no Brasil sobre crise na antropologia, segue de perto o que Krotz observou no México. Os atores intelectuais se dividem claramente entre os que estariam relativamente familiarizados com a disciplina, sem jamais tê-la praticado (dentre esses estariam colegas de outras disciplinas das ciências sociais ou das humanidades, interessados pela antropologia), e aqueles que nela militam profissionalmente. Não possuo evidência alguma de que estes últimos tenham se impressionado com qualquer ameaça de crise. Se eventualmente um ou outro membro da comunidade tenha se preocupado com a questão, isso seria um caso isolado. Mesmo porque aqueles colegas interessados em discutir a disciplina em nível epistemológico, ou seja, procurando dar conta dos paradigmas que a compõem (ou compuseram a antropologia ao longo de sua história), praticamente têm considerado a noção de crise como uma idéia pouco fecunda para a apreensão da disciplina, pelo menos em sua atualidade. Eu me situo dentre esses últimos - e meus trabalhos (2) sempre procuraram conduzir uma reflexão sobre a disciplina abstendo-se de qualquer ênfase maior em suas eventuais crises, passadas ou presentes, simplesmente (e aqui está o argumento) porque mesmo as turbulências que a antropologia sofreu em passado recente, não foram de molde a contaminá-la no nível epistêmico. Para ilustrar sucintamente o exposto, lembraria aos colegas pelo menos duas crises que tiveram lugar no país, uma que tocou profundamente a comunidade universitária (refiro-me às conseqüências do regime autoritário no interior do corpo docente de inúmeras universidades), outra (esta especificamente prejudicial à etnologia indígena) que transformou a FUNAI no maior obstáculo à pesquisa etnográfica, dificultando, quando não impedindo, para muitos jovens etnólogos 
o exercício do trabalho de campo junto às populações indígenas por ela tuteladas. Mesmo assim, não se pode dizer que a antropologia entrou em qualquer tipo de crise disciplinar ou metadisciplinar.

Entendo, portanto, que aquilo que poderíamos chamar de crise - volto a dizer: no plano epistemológico, e não no da organização do trabalho científico, na qual se incluiriam crises institucionais - só se observaria nos termos em que Kuhn a vem colocando. A saber, quando um paradigma sucede ao outro no processo histórico de transformação da ciência; ou, melhor, das ciências duras, ou hard sciences. Dispenso-me de alongar-me sobre o pensamento kuhniano a respeito, pois suas idéias têm sido bastante divulgadas mesmo no meio das soft sciences como o nosso. Diria apenas - e aqui reproduzo idéias que venho repisando já há algum tempo - que a antropologia moderna está constituída por um elenco de paradigmas simultâneos, ou, para usar uma expressão de Stocking Jr. (1980:419), trata-se de um "equilíbrio poliparadigmático". Todavia, menos do que tomar em conta a antropologia como um todo, isto é, os seus diferentes ramos, tenho focalizado a antropologia social (ou mesmo cultural, em sua acepção moderna), o que confere às minhas preocupações um teor bastante diferente das desse competente historiador da disciplina. Cinjo-me, assim, como têm demonstrado meus escritos - desde 1984, quando ministrei a conferência da XIV Reunião Brasileira de Antropologia - a procurar equacionar os paradigmas que compõem, em sua justaposição e simultaneidade, a matriz disciplinar da antropologia (3). Voltarei ao tema mais adiante para dar conta aos colegas de como penso hoje essa questão, agora relacionada com a chamada crise da disciplina.

Neste momento creio que será oportuno ilustrarmos com um bom exemplo a relação que tem lugar no interior da disciplina, na qual paradigmas e teorias convivem numa interação contínua. Penso que podemos exemplificar essa relação entre paradigmas e teorias na instância do parentesco, certamente a mais clássica que podemos identificar na antropologia, responsável mesmo pelo amadurecimento da disciplina ao longo de todo um século. Qualquer professor de antropologia sabe que as teorias de parentesco desempenharam historicamente um papel fundamental na formação de sua disciplina, posto que foi precisamente nessa instância empírica que ela logrou seus sucessos mais sólidos, seja como núcleo de muitas das melhores monografias, que se tornaram exemplares para a sua consolidação, seja como uma das instâncias mais suscetíveis de formalização, portanto capaz de proporcionar à antropologia abordagens de caráter nomológico. Seja como for, as teorias de parentesco - muitas vezes tão desprezadas hoje em dia no ensino da disciplina - são parte indispensável na formação do antropólogo, pois por meio delas o estudante sempre conseguirá um acesso bem mais seguro no domínio da antropologia (4).

Vejamos o que essas teorias nos ensinam sobre a natureza de nossa disciplina. Sabemos que houve tempo em que se conflitavam duas teorias de parentesco: uma, 
denominada de descendência, de inspiração anglo-saxônica, privilegiadora de relações perpendiculares, facilmente demonstráveis num diagrama de parentesco; outra, de aliança, debitária da tradição francesa (de Mauss a Lévi-Strauss), baseada na idéia de reciprocidade e marcada por relações expressas horizontalmente em nível de um diagrama no qual o matrimônio constitui nódulos analiticamente privilegiados. Teorias, tão diferenciadas em sua concepção, em lugar de levarem a disciplina a entrar em crise, foram, ao contrário, responsáveis por uma dinamização da antropologia de tal magnitude a ponto de tornarem-se complementares, articulando-se, portanto, entre si, como mostram diferentes autores, a exemplo de Dumont (1971) e Buchler \& Selby (1968). São autores que, apesar de inserirem-se em tradições diferentes e específicas (Dumont, no estruturalismo francês; Buchler \& Selby, no empirismo anglo-saxão), chegaram praticamente às mesmas conclusões no que diz respeito à articulação entre teorias respectivamente originárias de paradigmas historicamente sempre em oposição. A crise que, eventualmente, em algum momento, essas teorias poderiam ter sofrido foi rapidamente sanada pela descoberta óbvia de que nenhuma delas daria conta sozinha da realidade do parentesco e somente com a articulação complementar de ambas a disciplina poderia finalmente deslindar a complexidade do fenômeno.

Isso nos ensina que as crises em nível de teorias são sanáveis: ou pela eliminação de uma por outra; ou pela articulação das mesmas (como no exemplo mencionado); ou, ainda, pela convivência pacífica de teorias contrárias, porém não-contraditórias, das quais, aliás, a antropologia está plena. Estas últimas, graças às quais a antropologia conseguiu se consolidar como disciplina respeitável no reino das ciências sociais, são majoritariamente do tipo a que Merton chamou de teorias de médio alcance (middle range theories) e que não são outra coisa para nós do que aquelas descrições analíticas, com pretensões explicativas, contidas nas monografias produzidas sobre tal ou qual sociedade ou cultura. Apesar de muitas delas, ou todas, serem passíveis de restrições e de críticas, particularmente quando constróem modelos diferentes sobre uma mesma sociedade e/ou cultura, isso não significa que essas teorias não convivam de algum modo, compulsoriamente, uma vez que uma não dispõe de força suficiente - isto é, de argumentos - para eliminar a outra. A literatura etnológica está repleta de exemplos dessa ordem. Sem qualquer ironia poderíamos chamar isso de o afável convívio acadêmico entre monografias.

Essas teorias - diferença dos paradigmas, que mais seriam metateorias constituem interpretações de realidades concretas: seja focalizando sistemas sócioculturais globais, como as monografias clássicas concernentes a tal ou qual povo; seja procurando descrever e analisar sistemas parciais, como o parentesco, a mitologia, a religião etc., seja, ainda, através da investigação intensiva de um determinado tema ou problema, buscando dar conta, holisticamente, de um povo ou grupo social específico - como nas modernas monografias etnológicas (6). A quase totalidade da produção antropológica está orientada (queiram ou não os 
seus autores) para a construção de teorias de médio alcance contidas em monografias competentemente elaboradas. As grandes teorias são raras, na medida que ultrapassam instâncias empíricas específicas para atingir um nível de generalidade planetária. Prefiro mencionar, nesse sentido, apenas uma, talvez a mais conhecida hoje em dia, a construída por Lévi-Strauss (1949) para dar conta do parentesco: seu livro clássico Les structures élémentaires de la parenté pode ser tomado como boa ilustração de uma grande teoria.

Vamos agora nos deter um pouco sobre a noção de paradigma e de sua utilidade na antropologia. Procurarei ser bastante sucinto, pois tenho tratado disso com bastante freqüência e não quero estender essa conferência com longas explanações. Contudo, há de se dizer que o meu conceito de paradigma se origina em sua versão kuhniana, na qual as idéias de quebra-cabeça (puzzle solving) e de exemplaridade são co-extensivas da de paradigma: a primeira, denotando o caráter fechado e circular dos problemas e de suas soluções, ambos devidamente previstos pelo paradigma; a segunda, indicando a natureza modelar dessas soluções enquanto inscritas - no caso de nossa disciplina - em monografias exemplares. $\mathrm{O}$ caráter exemplar dessas monografias significa que as teorias de tal ou qual sistema sócio-cultural se amparam, em nível metateórico, em paradigmas facilmente identificáveis através da investigação epistemológica. A rigor, essas monografias exemplares expressam, em grau variável, seus pressupostos paradigmáticos. Mesmo para Kuhn, que está mais familiarizado com paradigmas constituídos por regras formalizadas, a noção de exemplaridade é naturalmente aceita quando se trata de ciências como as sociais ou humanas pouco afeitas à formalização. Mas ele fala ainda em matriz disciplinar como equivalente a paradigma. No meu entender, entretanto, cabe distingui-las como sendo duas noções.

Diria, assim, que se matriz disciplinar pode ser sinônimo de paradigma, enquanto encarna o poder matricial de um determinado conjunto de regras (o que faz sentido em ciências marcadas por sucessão de paradigmas ou matrizes); já ao se tratar de conjunto de paradigmas que se dão em simultaneidade (e não em sucessão), a idéia de matriz disciplinar torna-se bastante útil por permitir articular tais paradigmas numa única estrutura, inclusive, capaz de absorvê-los sem anular nenhum deles (o que ocorre, tipicamente, na antropologia - como tenho procurado demonstrar em outras oportunidades). Por isso não pretendo agora mostrar graficamente o que chamo de matriz disciplinar da antropologia. Bastaria indicar que tal matriz é constituída por quatro paradigmas básicos, historicamente demonstráveis:

- o racionalista (e estruturalista em sua acepção levi-straussiana), gerado no interior da tradição intelectualista européia continental através da Escola Francesa de Sociologia; 
- o estrutural-funcionalista, cuja origem se deu na tradição empirista igualmente européia, porém insular, através da Escola Britânica de Antropologia Social;

- o culturalista, também abrigado na tradição empirista anglo-saxônica, mas surgido na Escola Histórico-Cultural Norte-americana;

- o hermenêutico, vinculado à tradição intelectualista européia continental, reavivado, todavia, pelo movimento interpretativista norte-americano, em tentativa de recuperação tardia de uma perspectiva filosófica do século XIX.

Cabe lembrar, a propósito, que os três primeiros paradigmas são igualmente produto desse mesmo século, mas como subproduto da Ilustração, constituindo, o quarto paradigma, reação à razão iluminista. A esta reação é que se tem aplicado o termo pós-moderno, como uma espécie de oposição à chamada modernidade, inaugurada no Iluminismo, período de um quase religioso culto à razão. O pensador francês Jean-Francois Lyotard (1979) é bastante esclarecedor nesse sentido. Para justificar o tratamento tão sintético e incompleto que estou dando aqui à questão da matriz disciplinar, gostaria de lembrar que tive a oportunidade de desenvolver extensamente uma argumentação sobre essa temática nos quatro primeiros capítulos do livro Sobre o pensamento antropológico já mencionado. Consistentes ou não, os argumentos lá estão à disposição do leitor interessado em aprofundar a questão.

Mas o certo é que nem os três primeiros paradigmas, inspirados na episteme naturalista (como o de ver a antropologia como um tipo de ciência natural), nem o quarto, com sua crítica radical ao escopo naturalizante da disciplina, levaram ou estão levando - a antropologia à crise. Ver com olhos críticos os paradigmas da ordem - como denominei os três primeiros - não significa criar uma crise na antropologia, mesmo se se considerar a posição dos mais fanáticos pós-modernos, como um Stephen Tyler, por exemplo. Com a introdução pelo paradigma hermenêutico de alguma desordem na matriz disciplinar (constituída, originalmente, pelos paradigmas orientados pelas ciências naturais), o que se viu foi pelo menos em meu modo de ver - uma sorte de rejuvenescimento da disciplina. E isso graças ao aumento da tensão entre os paradigmas circunscritos na matriz: se essa tensão já havia entre aqueles primeiros paradigmas, com a inclusão do último ela aumentou em escala, dinamizando extraordinariamente a antropologia de nossos dias. Portanto, nunca é demais insistir que a hermenêutica não veio para erradicar os paradigmas, hoje chamados de tradicionais. Mas para conviver com eles, tensamente, performando uma matriz disciplinar efetivamente viva e produtiva. Tenho me valido de uma expressão de Paul Ricoeur, la greffe, ou seja, o enxerto, para exprimir o papel que a hermenêutica desempenha na matriz disciplinar. Um enxerto: 
- de moderação na autoridade do autor (com a eliminação de qualquer dose de autoritarismo);

- de maior atenção na elaboração da escrita (com a obrigatória tematização do processo de textualização das observações etnográficas);

- de preocupação com o momento histórico do próprio encontro etnográfico (com a conseqüente apreensão da historicidade em que se vêem envolvidos sujeito cognoscente e objeto cognoscível); e, finalmente, porém, não em último lugar,

- um enxerto de compreensão sobre os limites da razão científica, ou da cientificidade, da própria disciplina (o que não quer dizer que tal signifique abrir mão da razão e de suas possibilidades de explicação; para ser mais claro, continuo acreditando na razão e, para fazer eco às palavras de Habermas, diria que a modernidade ainda não se esgotou para começarmos a levar muito a sério essa pós-modernidade).

Vamos examinar de maneira tópica - o que significa dizer de modo não extensivo - um pouco mais cada um desses novos elementos que, graças à perspectiva hermenêutica, vieram se instalar no interior da matriz disciplinar como que a alimentá-la com os melhores nutrientes. É assim que ao se falar de autor(idade) estamos problematizando algo que nem sempre é levado em conta pelo pesquisador, portanto podendo ser facilmente transformada em autoritarismo, uma vez que o poder (lembremo-nos de Foucault) sempre presente e do lado da sociedade a que pertence o pesquisador, jamais é por ele próprio questionado. Tomemos apenas um aspecto desse encontro etnográfico, que me parece ser emblemático por sua natureza crítica: trata-se da relação pesquisador-informante, na qual o poder do primeiro contamina de resto toda a entrevista. Sabemos, hoje em dia, que se não for levada em conta tal situação, que condiciona o encontro etnográfico, a investigação antropológica nunca será iniciada de forma adequada. A condição de estar lá (o being there de que nos fala Geertz) (7) é - por várias razões, das quais essa é apenas uma - essencialmente crítica. Ela gera, por outro lado, uma autonomia que, a rigor, é ilusória. "Eu estive lá, portanto sou testemunha do que vi e ouvi", não passa de uma frase plena de significados no mínimo dúbios! Porque sob a intenção saudável do pesquisador se responsabilizar pelo fato que descreve e interpreta (ou descrevendo interpreta), esconde-se uma segunda intenção - é verdade que nem sempre consciente - de dar legitimidade ao seu discurso (quase que dogmatizando-o ao leitor: e isso vale tanto para os seus pares como para o leitor comum). O estar lá tende a não admitir dúvidas... Eis o seu caráter perverso.

Tal constatação, porém, não quer dizer que o estar aqui (being here) não carregue em si mesmo suas contradições. Geertz mostra o papel do ambiente 
universitário, desde o prosaico corredor onde as palavras são muitas vezes jogadas fora, até o gabinete de trabalho do professor, passando pelas bibliotecas, onde, aliás, fazemos uma segunda pesquisa: a library fieldwork. Não discutirei aqui todos os aspectos assinalados por Geertz, sempre bastante arguto em que pese sua inescapável tendência ao preciosismo verbal... Gostaria de limitar-me exclusivamente a apontar a instância do estar aqui, gozando as condições do trabalho de gabinete, como sendo em si mesma problemática, uma vez que ela necessariamente nos conduz à dinâmica dos jogos de linguagem, próprios de nossa disciplina (ou congêneres), de cuja atitude crítica - melhor diria: autocrítica não podemos nos furtar.

O certo é que tanto o estar no campo quanto o estar no gabinete, fazem parte de um mesmo processo de busca de conhecimento. Nesse sentido, a separação nunca é tão nítida como parece pretender Geertz. Isso porque nós sempre levamos o gabinete conosco quando vamos realizar a pesquisa de campo, tanto quanto trazemos o campo conosco quando voltamos ao nosso lugar de trabalho. Entendo que essa separação, ainda que seja real em termos de topos, de lugar, não determina qualquer processo esquizofrênico na personalidade do pesquisador/ autor. Lembro-me, à época em que eu ainda fazia etnologia, quantas vezes em meu diário de campo eu iniciava verdadeiros ensaios simultaneamente à etnografia que realizava. Mas Geertz está certo quando, ao separar as duas instâncias que, bem articuladas, criam o produto antropológico, dão-lhes o destaque devido, como duas faces que são de uma mesma moeda.

Mas a maior importância que vejo dentre esses novos elementos que passam a ser absorvidos pela matriz disciplinar (pelo menos assim espero) é o da historicidade, ou, em outras palavras, da consciência histórica que passa a habitar o horizonte do pesquisador. Excusado dizer que é a obra de Gadamer, Verdade e método, cuja primeira edição alemã é de 1960, a grande responsável pela renovação do pensamento hermenêutico que as ciências humanas e, particularmente, a antropologia, haveriam de incorporar, naturalmente de forma variável. No caso específico de nossa disciplina, o que se verificou foi o recrudescimento de certos componentes habituais do fazer antropológico, mas que, todavia, não chegavam a ser tematizados na órbita da disciplina e, por esse motivo, não ganhavam o desenvolvimento que mereciam. Refiro-me, de um modo todo especial, ao aprofundamento de uma maior reflexão a respeito da relação sujeito/objeto e de seu mútuo condicionamento histórico. Essa reflexão, entretanto, está longe de se inspirar num historicismo de origem diltheyana, mas, sim, no segundo Dilthey, o hermeneuta. Recuperada essa hermenêutica por Gadamer (passando, naturalmente, por Heidegger, seu mestre), dá-se um tipo muito especial de articulação epistêmica: a que envolve a história e a linguagem, como o meio, ou ambiente, em que se edifica a esfera da intersubjetividade. Em poucas palavras, em simplificação só justificável numa conferência, em que o tempo é extremamente limitado, diria que história, linguagem e intersubjetividade formam uma espécie de 
tripé sobre o qual se assentam as bases de uma reflexão a respeito de questões tradicionais na antropologia, presentes na obra de nossos clássicos como Malinowski, Boas ou Evans-Pritchard. Talvez a questão mais central, pois nuclear na constituição do conhecimento, seja a da relação sujeito cognoscente/objeto cognoscível a que já me referi.

De que elementos a antropologia se enriquece com a tematização de questões como a da relação entre observador e observado, pesquisador e pesquisado, antropólogo e informante? Primeiro, pode-se dizer, que ela ganha ao se interrogar sobre a especificidade de uma relação em que ambas as partes (observador e observado) estão situadas num mesmo momento histórico, querendo dizer que o sujeito cognoscente não está imutavelmente engessado numa posição intocável pelo objeto cognoscível: ele, tanto como o Outro, está inserido na dinâmica do encontro etnográfico. Em termos epistemológicos, diria que a objetividade concebida pelo positivismo, na qual o pesquisador daria todas as cartas, é puramente ilusória. Segundo, e em decorrência disso, a relação que se impõe entre as partes envolvidas no processo cognitivo, de monológica, passa a ser dialógica, alterando a própria prática da chamada entrevista com a transformação do pesquisador e de seu informante em interlocutores (significando isso que uma relação caracteristicamente marcada como uma via de mão única, passa a ser de mão dupla, conseqüência do diálogo tomado agora como essencial na busca - nem sempre e dificilmente alcançada, é verdade - de simetria nas relações entre pesquisador e pesquisado). Não faz muito tempo, o Anuário antropológico (1988) publicou um interessante artigo de Vincent Crapanzano, intitulado Diálogo, no qual esse antropólogo, ligado ao movimento interpretativista norte-americano, procura discutir o tipo de apreensão gadameriana da realidade examinando seu lugar no interior da própria experiência antropológica. Se na filosofia hermenêutica de Gadamer o dialogo e, com ele, a compreensão (Verstehen), é constitutivo do Homem (daí ser ela uma hermenêutica ontológica), para a antropologia a relação dialógica conduz as partes envolvidas à compreensão dupla - o que significa que o Outro é igualmente estimulado a nos compreender... Isso se dá graças a ampliação do próprio horizonte da pesquisa, incorporando, em alguma escala, o horizonte do Outro. Trata-se da conhecida fusão de horizontes de que falam os hermeneutas. Contudo, gostaria de enfatizar, em nenhum momento o antropólogo deve abdicar de posicionar-se no interior de seu próprio horizonte, isto é, minimamente no de sua disciplina, ela própria uma cultura científica de origem ocidental. Portanto, nessa fusão de horizontes o pesquisador apenas abre espaço à perspectiva do Outro, sem abdicar da sua, uma vez que o seu esforço será sempre o de traduzir o discurso do Outro nos termos do próprio discurso de sua disciplina. Há uma sorte de transferência de sentido de um horizonte para outro. Apesar da suspeição da razão levantada pela hermenêutica gadameriana (8), nem por isso essa razão estaria fadada à obsolescência... Apenas estaríamos levando em conta seus limites. 
E aqui chegamos à última parte desta exposição, momento em que precisamente vamos procurar mostrar como a compreensão hermenêutica e a explicação nomológica podem ser articuladas, antes de se oporem irremediavelmente como parecem querer os mais impenitentes pós-modernos. Por tudo que argumentamos até agora, espero haver deixado claro ao menos minha posição de não reconhecer qualquer crise na Antropologia, muito menos uma que se poderia denominar de epistemológica. Isso só seria possível se o paradigma hermenêutico tivesse vindo - ainda que tardiamente - para eliminar os paradigmas da ordem, comprometidos com a tarefa de explicar a cultura, a sociedade, enfim, o homem, em termos nomológicos; o que quer dizer naturalizando-os na maioria das vezes; e se digo na maioria das vezes, e não sempre, é que pelo menos no desdobramento lévi-straussiano do paradigma racionalista (desdobramento, portanto, não mais naturalizante, ainda que nomológico, e, assim, igualmente da ordem) o parâmetro não é mais a ciência natural, porém a lingüística, uma ciência humana. Por conseguinte, em lugar de eliminar todos os paradigmas da ordem, estamos vendo que a hermenêutica veio travar com eles uma batalha não de morte, mas de vida - revivificando-os e introduzindo na matriz disciplinar uma tensão extremamente saudável, em nada parecida com crise.

A esta altura gostaria de recorrer a dois autores, filósofos, cujas reflexões sobre a compreensão e a explicação abrem boas pistas para o trabalho do antropólogo. São eles, Karl-Otto Apel e Paul Ricoeur. Ambos procuram mostrar, cada um a seu modo, como o explicar e o compreender podem ser associados em empreendimentos cognitivos específicos. Mais uma vez mencionaria não nos permitir, o tempo de que dispomos, ir além de meras menções das idéias desses autores. Não obstante, creio que se justificam a título de sugestões de leituras mais completas e, certamente, mais avançadas, sempre possíveis de serem levadas avante. Pelo menos dois comentários eu gostaria de fazer inspirado em um e em outro autor. O primeiro comentário toma por referência o ensaio Cientística, hermenêtica e critica das ideologias, no qual Apel desenvolve a perspectiva de uma "mediação dialética entre a explicação das ciências sociais e a compreensão das tradições de sentido, própria das ciências histórico-hermenêuticas" (9). Embora suas reflexões estejam orientadas substancialmente para a questão ética (questão essa que, dada a sua relevância, em outras oportunidades eu mesmo a abordei e tendo por base o próprio Apel) (10), o que nos interessa agora assinalar é que Apel, ao reconhecer a critica das ideologias (a mesma de que fala Habermas), abre uma via bastante rica para a investigação em ciências sociais e, de modo todo especial, em antropologia. Se as ciências naturais empírico-analíticas, admitidas habitualmente como ciências, e as ciências hermenêuticas do espírito (sociais ou humanas) estão, as primeiras, orientadas pela infindável busca de objetividade (através da qual se exercita a razão instrumental, interventora na natureza) e, as segundas, pela necessidade de estabelecer sentido nas ações observadas (isto em conseqüência da obrigatória comunicabilidade intersubjetiva com vistas a acordos), o 
que se conclui é que do ponto de vista de nossa disciplina tanto um quanto outro tipo de ciência não deixa de desempenhar importante função no interior da matriz disciplinar. Os paradigmas que denominei da ordem, comprometidos com a objetividade custe o que custar, podem ser considerados como guardando uma relação dialética com o paradigma hermenêutico, ele próprio inexoravelmente comprometido com as conexões de sentido inerentes à esfera da intersubjetividade. Não tomando Apel (e nem Habermas) ao pé da letra, poderíamos dizer que mediante à crítica (e não apenas a crítica das ideologias), que permanentemente deve habitar o espaço da matriz disciplinar, o antropólogo estaria sempre visualizando os limites dos diferentes paradigmas componentes da matriz, o que o levaria a transcendê-los na prática da investigação.

Na transcendência dos paradigmas, proporcionada pela admissão tácita de que eles se encontram em permanente tensão (chame-a ou não de dialética), o importante é reconhecer a crescente unidade que marca a articulação entre os paradigmas da ordem e o hermenêutico, a partir do momento em que - e aqui me inspiro em Ricoeur - não se trata de uma questão de método o que separa os primeiros do último paradigma. A explicação, inscrita programaticamente nos paradigmas da ordem, não colide com a compreensão constitutiva da hermenêutica. Assim nos esclarece Ricoeur (1986:181): "Sobre o plano epistemológico, primeiramente, diria que não há dois métodos, o método explicativo e o método compreensivo. Para falar estritamente, apenas a explicação é metódica. A compreensão é sobretudo o momento não metódico que nas ciências interpretativas se compõe com o momento metódico da explicação. Este momento precede, acompanha, fecha e assim envolve a explicação. Em compensação a explicação desenvolve analiticamente a compreensão. Este elo dialético entre explicar e compreender tem por conseqüência uma relação muito complexa e paradoxal entre ciências humanas e ciências da natureza".

Para melhor entendermos o exposto nos termos de nossa disciplina, cabe ainda algum esclarecimento sobre a questão desse sentido alcançado pela compreensão. Diria, portanto, que enquanto a explicação dá conta daquelas dimensões do real suscetíveis de tratamento metódico (por métodos funcionais e/ou estruturais, por exemplo), a compreensão capta o que Ricoeur chama de excedente de sentido (surcroît de sens). Não é difícil para nós apreender, mesmo intuitivamente, o que significa esse excesso de sentido, desde que consideremos que tudo aquilo possuidor de alguma significação que seja irredutível a métodos, pode ser de alguma maneira recuperado pela via da compreensão. Aliás, é por aí que nos reencontramos com a distinção gadameriana entre verdade e método, segundo a qual toda a perdade (ou simplesmente a veracidade) não se alcança pelo caminho exclusivo do método. Esse algo mais que lhe escapa não só pode, mas deve ser alcançado pela via da compreensão. Se tomarmos isso como um alvo perfeitamente plausível da antropologia, estaremos admitindo que nossa matriz disciplinar expressa com razoável fidelidade a atual episteme da disciplina. 
Para concluir, acrescentaria apenas que a considerarmos por crise um sério obstáculo a ser transposto pela disciplina, ela - se existe - não tem qualquer repercussão em nível epistêmico. Quero crer que os argumentos até aqui apresentados conduzem a essa asserção. E gostaria de dizer que não me refiro exclusivamente à antropologia que fazemos no Brasil, porém à disciplina em sua dimensão planetária. Todavia, não poderia dizer o mesmo do ponto de vista de eventuais crises institucionais (que envolvem a organização do trabalho científico ou mesmo sua própria viabilidade em países carentes de tradição acadêmica ou, ainda, submetidos a regimes discricionários da liberdade intelectual). Entre nós, atualmente, a ordem institucional - em que pesem as dificuldades da conjuntura econômica - é ainda bastante favorável a empreendimentos de pesquisa e de ensino avançado, se não na maioria dos departamentos de antropologia do país, ao menos numa dezena deles, nos quais a disciplina já se consolidou ou está a ponto de consolidar-se. Como vêem, trago comigo uma visão otimista sobre a antropologia que fazemos no Brasil. Só espero que o tempo não me desminta.

\section{Notas}

l Com relação à sua aplicação nas ciências sociais, há pelo menos dois livros que eu gostaria de assinalar por possuírem especial importância para ilustrar o nível a que chegou o debate em torno de suas idéias: trata-se do volume Paradigms é revolutions: applications and appraisals of Thomas Kubn's philosophy of science (1980), no qual vários autores discutem a utilização da abordagem kuhniana nas ciências sociais e nas humanidades; e o pequeno livro de Barry Barnes, T.S.Kuhn and social sciences (1982), por meio do qual o autor realiza uma avaliação dos conceitos de paradigma e de ciência normal, a par de mostrar seus possíveis desenvolvimentos no campo das ciências sociais.

2 Particularmente os que estão enfeixados em meu livro Sobre o pensamento antropológico (1988).

3 A conferência em que a matriz disciplinar da Antropologia foi esboçada pela primeira vez, intitulei Tempo e tradição: interpretando a antropologia, tendo sido publicada no Anuário antropológico, (1984) posteriormente inserida em Sobre o pensamento antropológico.

4 Considere-se, por exemplo, que as teorias de redes (networks) que há décadas atrás foram desenvolvidas pela Escola de Manchester, podem ser consideradas como uma transposição dos instrumentos de análise de relações primárias, interpessoais, de sociedades ditas simples, para sociedades complexas, particularmente as urbanizadas. Ambas as teorias, de parentesco e de redes, cobrem instâncias praticamente equivalentes do ponto de vista teórico-metodológico. No primeiro capítulo de meu livro Enigmas e soluções (1983) vali-me da oposição complementar das teorias de descendência e de aliança para mostrar como se dá a articulação entre teorias a despeito da diferença existente entre seus respectivos paradigmas. 
5 Louis Dumont, especialmente em seu livro Introduction à deux théories d'anthropologie sociale, de 1971); Ira R. Buchler \& Henry A. Selby, em Kinship and social organization: an introduction to theory and method, publicado em 1968.

6 Só para ilustrar o que entendo a respeito de uma monografia moderna, construída através de uma problemática central, menciono o livro de Victor Turner, Schism and continuity in an African society, Manchester University Press, 1957.

7 Tanto o being there quanto o being here são expressões bem apropriadas utilizadas por Clifford Geertz em seu interessante Works and lives: the anthropologist as author, Stanford University Press, 1988. A bibliografia a respeito desse movimento, que se chama antropologia interpretativa, reúne algumas dezenas de bons artigos publicados em revistas especializadas estrangeiras. Dentre as revistas nacionais, destaco o Anuário antropológico (ns. 83, 84, 85, 86 e 88), pioneiro em colocar em discussão no Brasil a questão hermenêutica.

8 Recomendo aqui a leitura do pequeno ensaio de Gadamer, The hermenentics of suspecion, em Hermeneutics: questions and prospects. G.Shapiro \& A.Sica (orgs.). The University of Massachusetts Press, 1984.

9 Cf. Roberto Cardoso de Oliveira, O saber, a ética e a ação social, em Manuscrito: Revista Internacional de Filosofia, v. XIII, n.2, p. 7-22, out. 1990; Prácticas interétnicas y moralidad: Por un indigenismo (auto)crítico, em América Indígena, v. L, n. 4, p. 925, out./dez. 1990; Antropologia e moralidade, em Revista Brasileira de Ciências Sociais. ANPOCS, v. 9, n.24, p. 110-121, 1994.

\section{Referências bibliográficas}

APEL, Karl-Otto. Scientistic, hermeneutics and the critique of ideology. In: Towards a transformation of philosophy. Routledge \& Kegan Paul, 1980; ed. espanhola La transformación de la filosofia, t. II, Taurus Ediciones, 1985.

KROTZ, Esteban Krotz (org.). El concepto "crisis" en la historiografia de las ciencias antropológicas. Editorial Universidad de Guadalajara, 1982.

LÉVI-STRAUSS, Claude. A crise moderna da antropologia. Currier de l'Unesco, nov. 1961. Traduzido e republicado em Revista de Antropologia, v. 10, n. 1/2, 1962.

LYOTARD, Jean-François. La condition postmoderne. Minuit, 1962.

MERLEAU-PONTY, Maurice. De Mauss à Claude Lévi-Strauss. In: Signes, Gallimard, 1960.

RICOEUR, Paul. Expliquer et comprendre: sur quelques connexions remarquables entre la théorie du texte, la théorie de l'action et la théorie de l'histoire. In: Du texte à l'action. Essais d'herménentique, II, Éditions du Seuil, 1986. 
STOCKING JR., George. Anthropology in crisis? A view from between generations. In: Crisis in anthropology. View from Spring Hill, 1980, Garland Publish.Inc., 1982.

Roberto Cardoso de Oliveira, antropólogo, é membro do Instituto de Filosofia e Ciências Humanas (IFCH) e do Centro de Lógica, Epistemologia e História da Ciência (CLE), ambos da Universidade Estadual de Campinas (UNICAMP).

Palestra feita pelo autor no seminário Ciência e sociedade: a crise dos modelos, realizado em 19 de novembro de 1993, na Universidade Federal do Paraná. 